\title{
Webinar Learning Strategies: Efforts to Increase Student's Activeness and Learning Achievements in the New Normal Period in Public Policy Course
}

\author{
Evi Susilawati ${ }^{*}$, Imamul Khaira ${ }^{2}$ \\ ${ }^{1}$ Faculty of Education and Teaching Training, Universitas Islam Sumatera Utara, Indonesia \\ ${ }^{2}$ Faculty Social Humanities and Education, Universitas Haji Sumatera Utara, Indonesia
}

*Corresponding author:

E-mail:

evisusilawati@fkip.uisu.ac.id

\begin{abstract}
Because to improve student activities and learning outcomes in this pandemic mass is the teacher's main task. To develop these competencies, one option is to use a seminar website or webinar as a learning strategy that can be applied to students. However, little is known about the process of improving student activity and learning outcomes through webinars. The purpose of this study was to increase student activity and learning outcomes during the pandemic in public policy courses through webinar learning strategies. This study uses classroom action research methods which were carried out at the Islamic University of North Sumatra with the participation of 10 students. The instruments used in this study were observation sheets, student assessments, and interview sheets. The results showed that there was an increase in student learning activities, especially in refuting activities or accepting other friends' ideas. The results of this classroom action research show that there is an increase in the activeness and learning achievements of students during the New Normal period in the public policy course using the webinar strategy.
\end{abstract}

Keywords: Students' activeness, public policy, webinar strategy, learning achievement.

\section{Introduction}

The implementation of physical distancing during the New Normal period is still being carried out because the spread of Covid-19 has not ended. Due to COVID-19, the local government does not impose a continuous lockdown because it affects education and the economy in Indonesia, so the implementation of the new normal. New normal is a renewal in normalizing activities during a pandemic with limitations, either physical distancing or social distancing to avoid or reduce the spread of the COVID-19 virus. New Normal has been an effort to optimally prepare for outdoor activities. Therefore, the community must be able to adapt to carrying out new changes in behavior patterns. Of course, these changes must be implemented globally by implementing health protocols to prevent the COVID-19.

During this New Normal period, the Islamic University of North Sumatra (UISU) took a policy to the held learning process by using e-learning. After an academic year implementation, e-learning at UISU has generated many problems. Based on preliminary observations made by researchers, there are three main categories of online learning problems, namely: problems related to students in the e-learning process, lecturers, and course material development. Students' problems in e-learning are: (1) students' low expectations in taking courses in which students think that elearning is just games; (2) students' readiness, such as lack of funds to buy internet quota and unreachable signals prevent them from being able to attend lectures in full; and (3) students participation in e-learning are low which is caused by low student expectations and low student readiness. The lecturers' problems are as follows: (1) the transition from face-to-face learning to e- 
learning must make lecturers unable to manage their time; and (2) their teaching technique using e-learning (Susilawati, 2020). Furthermore, the subject matter content problems were found as follows: (1) lecturers were unable to develop material following the characteristics of e-learning; (2) lecturers are unable to integrate multimedia-based learning material content; (3) the teaching style of the lecturer who still uses the lecture method in e-learning makes students bored and unable to understand the material presented by the lecturer (Susilawati \& Khaira, 2021).

Based on observations that have been carried out by researchers on seventh-semester students of the Pancasila and Civic Education Study Program, Faculty of Teacher Training and Education at the Islamic University of North Sumatra (UISU), they have a low level of learning activeness. The situations show that student learning achievements are still low. One of the strategies that can stimulate student activeness and learning outcomes during the New Normal period is to use Webinar Learning Strategies. Seeing the many problems in using e-learning during the Covid19 pandemic, UISU continues to strive to make various learning innovations so that the quality of learning activities can continue to be improved during this New Normal period. To solve this problem, e-learning at UISU needs to be equipped with online technology. In this online learning activity, lecturers and students are required to have ICT tools to enhance the student learning experience (Ryan et al., 2019). This online technology can take the form of a webinar.

This webinar can be used as a learning strategy that can activate students where they can interact directly, through pictures, videos, and text. Based on research conducted by Mayorga et al. (2018), it is stated that webinars are indispensable for learning activities at this time because webinars have the following characteristics: (1) orientation for collaborative and teamwork can be carried out, (2) providing the convenience of using technology, especially the Internet, (3) can be used with multitasking preferences such as watching TV, browsing the internet, and sending telephone text messages simultaneously, (4) can use an andragogy approach that focuses students on the importance of relevant material content to their activeness during the learning process, (5) able to motivate students to learn while working, (6) able to provide good feedback on learning achievements, (7) provide new abilities for students to develop students' critical thinking skills, (8) constitute technology new learning for the professional generation. In line with the results above, Rao (2019) argues that webinars are an umbrella of educational technology that can use various tools and various learning methods and can encourage the development of skills of various student skills in creating effective learning.

Seeing the usefulness and effectiveness of using webinars in learning activities, researchers use this learning innovation in the implementation of learning in Public Policy courses. Rinfret, Scheberie, \& Pautz, (2018) defines public policy, namely actions that are made and/or enforced, usually by the government, in response to public problems in the real world. Public policies are not only in written form which has become laws and regulations but also in the form of statements disclosed by government officials which are immediately followed up in various programs for a specific purpose. Public policies that give birth to various laws, of course, are only issued by the government. Therefore, students need to be given an understanding of public policymaking and the implementation of public policies must be consistent and must match the objectives of policymaking and policy implementation in the field. Through this Public Policy course, students are given the ability to analyze public policy issues using concepts, theories, and methods in public policy. The competencies of the Public Policy course above must be fully mastered by students in learning activities during the New Normal period. So, the purpose of this research is to find out the increase in student activity and student achievement when using webinar learning strategies during the COVID-19 pandemic. 


\section{Material and Methods \\ Research methods}

This research is a classroom action research. The selection of research subjects is based on the consideration that the researcher is a lecturer in the Public Policy Course. Observation guidelines are arranged based on the activity indicators of lecturers and students, namely: 1) answering questions, 2) asking questions, ideas, or responses, 3) finishing assignments, 4) refuting or approving other friends' ideas. Learning achievements are seen from the achievement of student learning Achievements in the Public Policy Course. The learning achievements instruments used to collect data in this study were 1) initial conditions and post-test for Public Policy Course, and 2) observation sheets of student activeness in attending Public Policy Course.

\section{Participants and subject}

The research activity was carried out on the seventh-semester students of the Pancasila and Civic Education Study Program, Faculty of Teacher Training and Education at the Islamic University of North Sumatra (UISU) with a total of 10 students. The selection of participants in this study was based on a purposive sampling technique which selected 10 students from a total of 120 students. These 10 students consisted of 5 male students and 5 female students consisting of the age range of 19-21 years.

\section{Instrument}

The action in this study was carried out in three cycles. Every important action from the three cycles is recorded and used as material for reflection and improvement to plan the next action to be carried out; 1) interviews, 2) documentation, 3) test methods. This research instrument was developed by the researcher together with the teaching team by maintaining the validity of the content. Observation guidelines are used to get a direct picture of increasing student activity and learning achievements using the Webinar Learning strategy. Data processing using qualitative data with the method of collection is carried out systematically with standardized procedures and the data collected is following the problem under study. Data collection was carried out in the following manner, 1) observation, the results obtained from the observation; 2) field notes, field notes are used to record important events that occurred during the learning process of the Public Policy Course. The things that need to be observed are divided into 3 parts, namely: (a) observation of teaching actions that are adjusted to the semester learning plan, (b) observation of learning actions related to student reactions and initiatives in learning Public Policy Course, and (3) additional information relating to the act of teaching and learning that has not been recorded.

\section{Data analysis}

In this study, the data were analyzed quantitatively and qualitatively. Quantitative data were analyzed descriptively quantitatively, namely calculating the mean of each activity in the cycle along with the value of n-gain to measure the increase in each cycle. The value of n-gain can be determined by the percentage of n-gain if the range of $56 \%-75 \%$ is classified as quite effective, while more than $76 \%$ is classified as effective. Qualitative data were analyzed by time triangulation, which was done by collecting data at different times which was carried out in 3 research cycles.

\section{Results and Discussion}

The results of the study were the result of collaboration between the teaching team of lecturers in the subject of Public Policy for Pancasila and Civic Education Study Program, Faculty of Teacher Training and Education at the Islamic University of North Sumatra (UISU) in the 2020/2021 academic year. The results of the discussion, dialogue, and collaboration are recommended to implement webinar learning strategies in Public Policy Courses so that learning Public Policy Courses 
can increase activeness and learning Achievements of Public Policy Courses increase. In order to increase the activeness and learning Achievements of the Public Policy Course, lecturers always make improvements to the implementation of classroom action research by implementing webinar learning strategies.

The formulation of the first problem that needs to be answered in this study is: "Is there an increase in student learning activeness after learning using webinar learning strategies?". After conducting the research, the following results were obtained: there was an increase in learning activeness in the Public Policy Course. Actions taken by lecturers to increase student learning activeness in Public Policy Courses are by implementing webinar learning strategies. The aim is to create an interesting, active, challenging, and fun atmosphere for learning Public Policy Courses so that students are motivated to learn. The increase in learning activeness in the Public Policy Course occurs following the indicators set by the researchers, namely: a) answering questions, b) asking questions, ideas or responses, c) finishing assignments, d) refuting or approving other friends' ideas. The learning achievements are seen from the achievement of scores in the student Public Policy Course $\geq 80$. Based on the results of observations of learning activities in Public Policy courses, it can be seen that there is an increase in student learning activeness in learning Public Policy courses. The following table 1 shows the student activeness data during the learning of the Public Policy course using the webinar learning strategy.

Table 1. Increasing student activeness in public policy course using webinar learning strategies

\begin{tabular}{|c|c|c|c|c|c|}
\hline No & $\begin{array}{c}\text { Students Active- } \\
\text { ness }\end{array}$ & Pre-learning & Action/Cycle I & Action/Cycle II & $\begin{array}{l}\text { Action/Cycle } \\
\text { III }\end{array}$ \\
\hline 1 & $\begin{array}{l}\text { Answering } \\
\text { Questions }\end{array}$ & $\begin{array}{l}3 \text { Students } \\
(30 \%)\end{array}$ & $\begin{array}{l}5 \text { Students } \\
(50 \%)\end{array}$ & $\begin{array}{l}7 \text { Students } \\
(70 \%)\end{array}$ & $\begin{array}{c}10 \text { Students } \\
(100 \%)\end{array}$ \\
\hline 2 & $\begin{array}{l}\text { Asking Ques- } \\
\text { tions or Idea }\end{array}$ & $\begin{array}{l}2 \\
(20 \%)\end{array}$ & $\begin{array}{l}3 \quad \text { Students } \\
(30 \%)\end{array}$ & $\begin{array}{l}6 \quad \text { Students } \\
(60 \%)\end{array}$ & $\begin{array}{l}9 \quad \text { Students } \\
(80 \%)\end{array}$ \\
\hline 3 & $\begin{array}{l}\text { Finishing As- } \\
\text { signments }\end{array}$ & $\begin{array}{ll}5 & \text { Students } \\
(50 \%) & \end{array}$ & $\begin{array}{l}7 \quad \text { Students } \\
(70 \%)\end{array}$ & $\begin{array}{l}8 \quad \text { Students } \\
(80 \%)\end{array}$ & $\begin{array}{l}10 \quad \text { Students } \\
(100 \%)\end{array}$ \\
\hline 4 & $\begin{array}{l}\text { Refuting or Ac- } \\
\text { cepting Other } \\
\text { Friends' Ideas }\end{array}$ & 1 Student (10\%) & $\begin{array}{l}3 \quad \text { Students } \\
(30 \%)\end{array}$ & $\begin{array}{l}5 \quad \text { Students } \\
(50 \%)\end{array}$ & $\begin{array}{l}9 \quad \text { Students } \\
(90 \%)\end{array}$ \\
\hline
\end{tabular}

Table 1 shows changes in learning activities related to the activeness of semester VII students of the Pancasila and Civic Education Study Program, Faculty of Teacher Training and Education at the Islamic University of North Sumatra (UISU) in learning Public Policy Course from before and after giving treatment are carried out. Based on the table, it can be argued that there was an increase in student activity in the learning of Public Policy subjects after learning by using learning strategies for the Public Policy Course.

The formulation of the second problem that needs to be answered in this study is: "Is there an increase in student learning achievements in Public Policy after using webinar learning strategies?". After the research was carried out, the results were obtained to show that there was an increase in learning achievements in the Public Policy Course using webinar learning strategies. Actions taken by lecturers to improve student learning achievements are by implementing webinar learning strategies. The goal is for students to work together in solving problems, creating an interesting, active, challenging, and enjoyable learning atmosphere so that students are happy to learn. The indicators of learning achievements in the Public Policy course in this study are students achieving $\geq 80$ grades of student Public Policy Course. Students achieve a score of $\geq 80$, meaning that students are indirectly motivated by their peers to achieve the highest score. Students can achieve a Public Policy Course score of $\geq 80$ from before the action to action III has a significant 
increase. This is because in the implementation of the webinar learning strategy, many students dare to express their opinions and refute or agree with friends' ideas and do their assignments well. With the addition of these points, it can foster the activeness and enthusiasm of each student to be active in learning activities for Public Policy courses. Based on the pretest and posttest actions I to action III learning activities for Public Policy Courses, it can be seen that there is an increase in student learning outcomes in learning Public Policy Courses. The following table 2 shows the data on the improvement of student learning achievements while participating in the Public Policy Course learning using the webinar learning strategy.

Tabel 2. Increasing of student learning outcomes in public policy subjects using webinar learning strategies

\begin{tabular}{llcccc}
\hline No & Student Activeness & Pre-Test & $\begin{array}{c}\text { Post Test Ac- } \\
\text { tion/Cycle I }\end{array}$ & $\begin{array}{c}\text { Post Test Ac- } \\
\text { tion/Cycle II }\end{array}$ & $\begin{array}{c}\text { Post Test Ac- } \\
\text { tion/Cycle III }\end{array}$ \\
\hline 1 & $\begin{array}{l}\text { Achievement of } \\
\text { Student Learning } \\
\text { Achievements with } \\
\text { score } \geq 80\end{array}$ & $\begin{array}{c}\text { 3 students } \\
(30 \%)\end{array}$ & $\begin{array}{c}5 \text { students } \\
(50 \%)\end{array}$ & $\begin{array}{c}7 \text { students } \\
(70 \%)\end{array}$ & $\begin{array}{c}10 \text { students } \\
(100 \%)\end{array}$ \\
\hline
\end{tabular}

Table 2 shows the data on the improvement of student learning outcomes who obtained a test score of learning achievements in Public Policy Course (score minimum to pass is 80 ) by $30 \%$. Then those who can obtain a test score of learning achievements for the subject of Public Policy (score minimum to pass is 80 ) in post-action I am $50 \%$, action II are $70 \%$, and action III are $100 \%$. Based on table 2 above, the results of classroom action research in cycle I to cycle III have shown that there is an increase in student learning achievements in the subject of Public Policy. The increased activeness and learning achievements of the Public Policy Course obtained during this research are as shown in Figure 1.

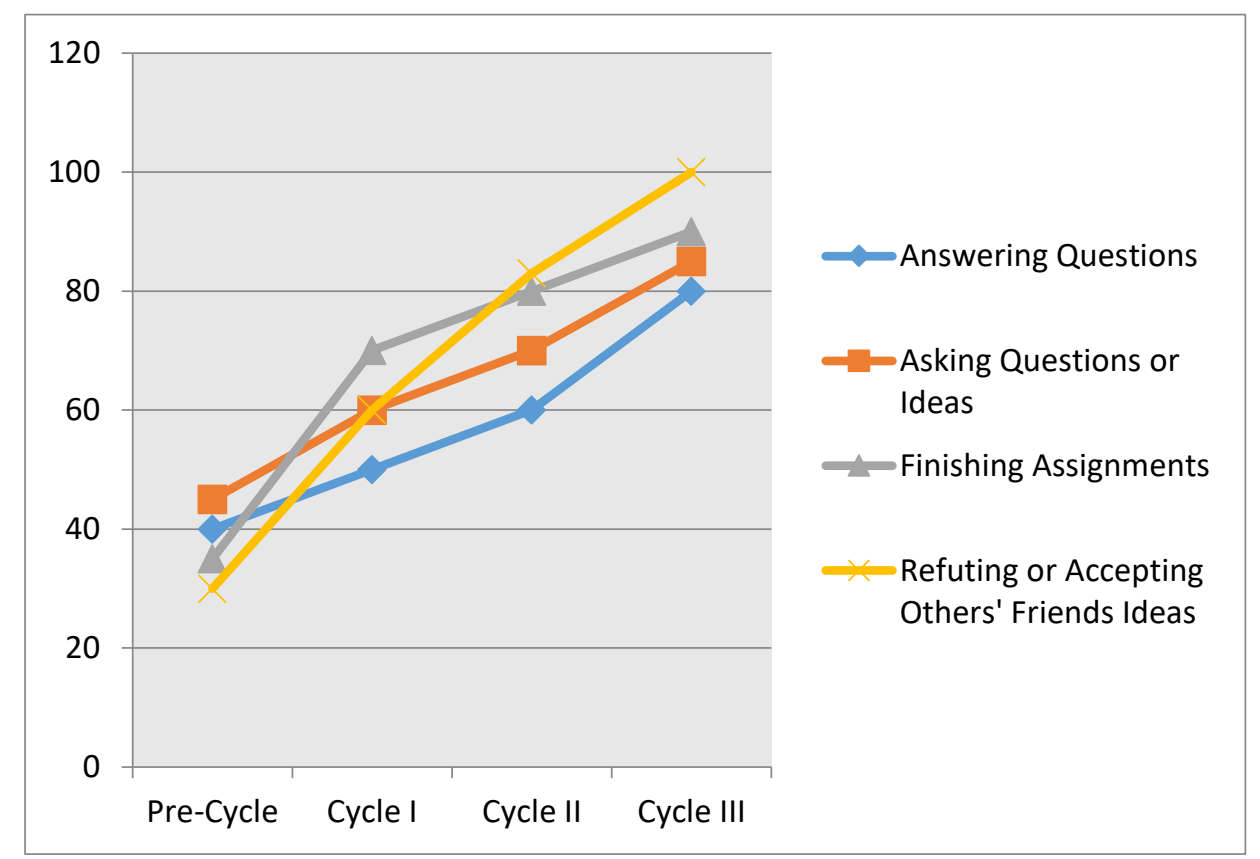

Figure 1. Data on the results of increasing student activeness in public policy courses using webinar learning strategies 


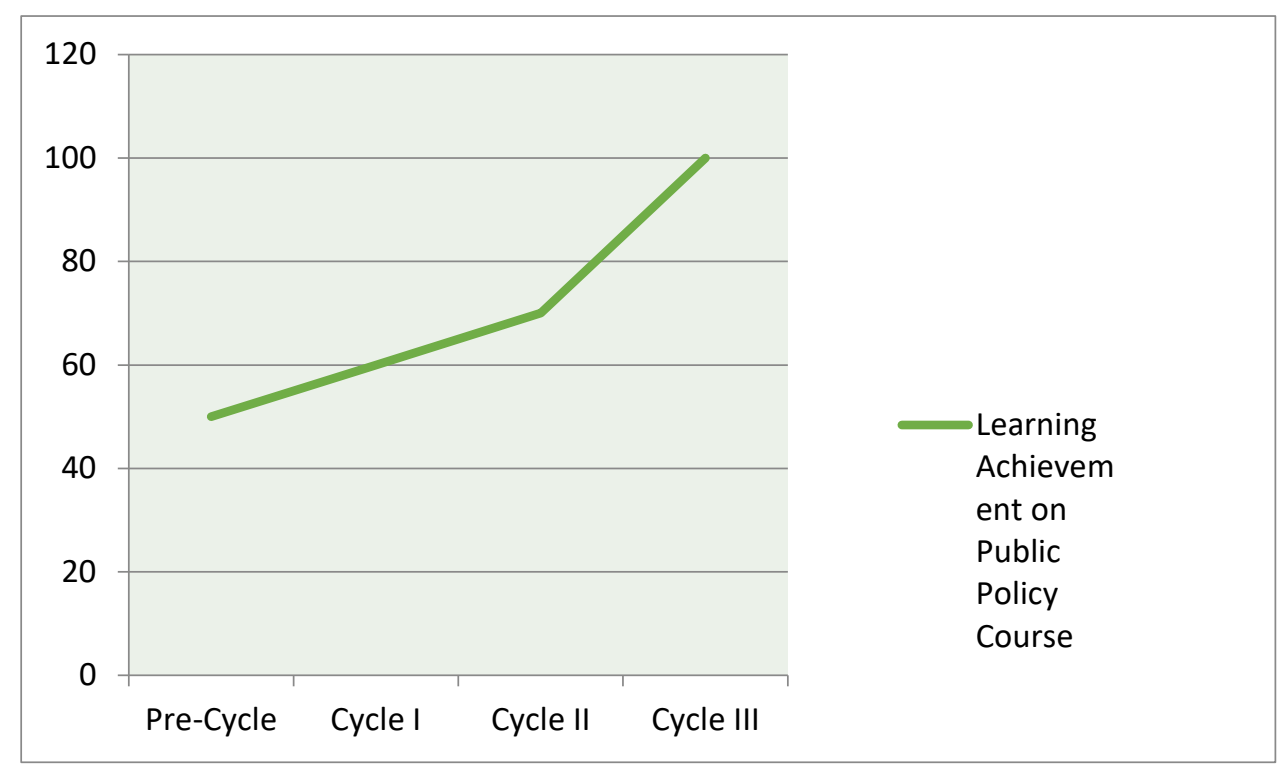

Figure 2. Data on results of increasing student learning achievements in public policy course using webinar learning strategies

Figure 1 and Figure 2 show the increase in the activeness and learning achievement of Public Policy Courses starting from pre-cycle / pre-cation to cycle III/action III by implementing a webinar learning strategy. The increase in student activity and learning achievement in the Public Policy course has increased because the webinar learning strategy creates learning that can create collaborative and online teamwork to motivate students to learn and provide new abilities for students to develop their critical thinking skills. The implementation of the webinar learning strategy has increased the activeness of learning in the Public Policy course for VII semester students of the Pancasila and Civic Education Study Program, Faculty of Teacher Training and Education at the Islamic University of North Sumatra (UISU). This supports the acceptance of the classroom action research hypothesis, namely that if the lecturer applies the webinar learning strategy in learning the Public Policy course, it will increase student activity and learning achievement.

The results showed that using the webinar learning strategy could improve student learning activities in public policy, especially on the indicator refute or agree with other students' ideas, this shows that there was an increase in student learning activeness in taking Public Policy courses through a webinar learning strategy The findings of this study are in line with the research findings put forward by Mayorga et al. (2018) which are very effective in online learning because they can invite students to collaborate online and can motivate students to learn and provide students with critical thinking skills. The results of this study also support Rao's research (2019) which suggests that the application of a webinar learning strategy can use a variety of tools and a variety of learning methods and create effective learning. By linking the teaching materials using various learning methods and using various online media, the use of webinar learning strategies in the Public Policy course can attract students' attention to learn more actively. Students can find their knowledge after group activities with the guidance of teacher lecturers in online classes.

At the same time, the webinar format, whether employed as a stand-alone learning event or as part of a blended solution, is not without limitations (de Rosa \& Johnson, 2019; Leung, 2020). Case studies tend to demonstrate that both students and learners continue to confront technical problems when using the platform, ranging from an internet connection and broadband issues to difficulty using webinar tools. Among these, the uneven level of technology awareness by users is a significant obstacle and calls for increased investment in the training of students an awareness of the advantages and disadvantages of using webinars (Amhag, 2013). Finally, perhaps the greatest 
challenge of the webinar format is the significant change in activeness learning and learning achievement that it brings about: shifting from preidentified and stable learning content to content that is flexible and co-created with users, which asks both students and learners to embrace a vision of learning that is collaborative and participative (Gegenfurtner \& Ebner, 2019; Mishra, et al., 2020).

\section{Conclusion}

Based on the results of classroom action research, it can be concluded that webinar learning strategies can increase activeness and learning achievement in Public Policy courses. This can be seen from the following indicators: There was an increase in student learning activeness in taking Public Policy courses through a webinar learning strategy with indicators: (a) students who dared to answer questions in pre-action through observation activities were recorded; (b) students who actively ask questions in pre-action through observation activities were recorded (c) students who did assignments in preaction through observation activities were recorded (d) students who refute or agree with other students' ideas in pre-action through observation activities are recorded. There was an increase in student learning achievement in the Public Policy course using the webinar learning strategy. This can be seen from the achievement of student learning achievement with scores of $\geq 80$ in the pre-test by $30 \%$, post-action I by $50 \%$, post-action II by $70 \%$, post-action action III by $100 \%$.

Based on the results of this classroom action research to increase the activeness and learning achievement of Public Policy courses through webinar learning strategies, several suggestions are proposed as follows towards a lecturer who teaches Public Policy Course like in online learning activities, lecturers who teach Public Policy courses should provide online attention and guidance to students and be friendly towards students so that students dare to express their opinions. Lecturers who manage Public Policy courses should implement learning strategies that pay attention to student abilities, that is, each student has different abilities so that students feel the same attention and can create student learning activities. Lecturers of Public Policy courses should not dominate online learning activities, because students tend to be bored and sufficient as facilitators. Towards Students should familiarize themselves with deepening the material that has been studied and studying the material that will be studied next, have the courage to ask questions about material that has not been understood, have responsibility for the homework given, and can work together in managing the class so that the class is comfortable for studying.

\section{References}

Amhag, L. (2013). Collective Webinars in Higher Distance Education', in T. Bastiaens and G. Marks (eds), Proceedings of e-learn: World conference on e-learning in corporate, government, healthcare, and higher education 2013 (Chesapeake, VA: Association for the Advancement of Computing in Education (AACE)). Available at https ://www.researchga te.net/publication/26218 2691/down (accessed 30 July 2019).

de Rosa, C., \& Johnson, J. (2019). Webinar-based approaches to maximize learning and transfer good practices: case studies from the humanitarian sector. International Journal of Training and Development, 23(4), 339-348.

Gegenfurtner, A., \& Ebner, C. (2019). Webinars in higher education and professional training: a meta-analysis and systematic review of randomized controlled trials. Educational Research Review, 28, 100293. https://doi.org/10.1016/j.edurev.2019.100293

Leung, D. Y., Chan, E. A., Wong, A. K., Reisenhofer, S., Stenberg, M., Sze, C. P., Lai, K. H., Cruz, E., \& Carlson, E. (2020). Advancing pedagogy of undergraduate nursing students' cultural awareness through internationalization webinars: A qualitative study. Nurse Education Today, 93, 104514. DOI: 10.1016/j.nedt.2020.104514

Mayorga, E. P., Bekerman, J. G. \& Palis, A. G. (2014). Webinar software: A tool for developing more effective lectures (Online or in-person). Middle East African Journal of Ophthalmology, 21(2), 127. 
Mishra, L., Gupta, T., \& Shree, A. (2020). Online teaching-learning in higher education during lockdown period of COVID-19 pandemic. International Journal of Educational Research Open, 1, 100012.

Susilawati, E. (2020). Upaya Meningkatkan Keaktifan Mahasiswa Dalam Menganalisis Video Pembelajaran Melalui Strategi Pembelajaran Webinar. Jurnal Teknologi Pendidikan, Vol. 13, No. 2, Maret 2020. Doi: https://doi.org/10.24114/itp.v13i2.

Susilawati, E. \& Khaira, I. (2021). Implementasi E-Leraning Flipped Classroom Sebagai Upaya Peningkatan Kemampuan Mahasiswa Dalam Mendesain Materi Pengembangan Bahan Ajar Non Cetak. Jurnal Teknologi Pendidikan, 14(1), April 2021. Doi: 10.24114/jtp.v.24105.

Rao, P. (2019). Webinars and Their Effective use in English Language Teaching and Learning. ELT Vibes: International E-Journal for Research in ELT, 5(1), 73-97.

Rinfret, S., Scheberie, D., \& Pautz, M. (2018). Public Policy: A Concise Introduction. New York: SAGE Publications.

Ryan, T., Henderson, M. \& Phillips, M. (2019). Feedback modes matter: comparing student perceptions of digital and non-digital feedback modes in higher education. British Journal of Educational Technology, 50(3), 1507-1523. doi: 10.1111/bjet.12749. 